\title{
Comentários sobre analogias e diferenças entre os métodos Paidéia e o "interrogativo"
}

\author{
Gastão Wagner de Sousa Campos ${ }^{1}$
}

O convite dos editores da Interface para este debate muito me honra, além de constituir excelente oportunidade para expor minhas concepções em diálogo com o instigante ensaio de Luis Cecílio. Ele elaborou um trabalho criativo que interroga tanto a tradição dominante quanto as correntes que pretendem inovar teorias e práticas em gestão, as quais defendo.

Começarei pelo fim. Cecílio termina seu artigo com duas interrogações: seria possível a construção de uma metodologia anti-Fayol e haveria uma sétima função gerencial além daquelas pensadas para "produzir" o "trabalhador funcional"? É claro que tenho respondido de modo afirmativo a essas indagações, tanto que, ainda na década de 1990 publiquei um ensaio intitulado: "O anti-Taylor: um método para co-governar instituições produzindo liberdade e compromisso" (Campos, 1998). Eu criticava o que denominei de "racionalidade gerencial dominante", e que incluía as concepções de Taylor, Fayol, bem como de seus desdobramentos contemporâneos (qualidade total, toytismo, gestão de resultados etc). Em trabalho posterior apresentei um conjunto de conceitos operativos a que chamei de Paidéia: "um método para análise e co-gestão de coletivos"; (Campos, 2000). Esta metodologia baseia-se em dois eixos: a democratização das organizações mediante a constituição de sistemas de co-gestão; e a utilização de uma sétima função gerencial, o apoio Paidéia, objetivando a co-constituição de trabalhadores com capacidade de articular os próprios valores e interesses com a racionalidade dos outros, do coletivo e das organizações. A co-gestão é um movimento político, de desconcentração do poder em organizações que somente ocorrerá quando trabalhadores tenham potência para disputá-lo.

A eleição desse caminho indica haver diferenças entre o discurso de Cecílio e o meu. Apontarei algumas. Considero o método interrogativo, o único conveniente segundo Cecílio, necessário mas insuficiente. É potente para estimular a reflexão e evitar o dogmatismo, o que não é pouco, ao contrário; entretanto, não se constitui numa teoria da ação. Essa metodologia estimula a contemplação e o espírito crítico, mas não é suficiente para o manejo de campos aplicados que exigem tomadas de decisão e intervenção. Considero que o conceito de praxis apresentado por Marx \& Engels (1845/ 1996) nas "Teses sobre Feuerbach" aplica-se melhor ao tema debatido porque reconhece 
a interdependência entre teoria e prática, entre trabalho morto e vivo (em ato), entre tradição e inovação. Parece-me que Pichon-Rivière $(1988,1989)$ com sua concepção sobre "grupo operativo" e "teoria do vínculo" - utilizada para compreender as relações inter-subjetivas e sociais entre trabalhador e usuário - logrou desdobrar aquela concepção, aplicando-a com criatividade às organizações. Recentemente Castoriadis (1982) deu continuidade a esta linha de pensamento; o método Paidéia filia-se a esta tradição.

Assim, opero com a noção de que a autonomia do trabalhador - e do ser humano em geral - caracteriza-se pela capacidade de lidar com sua própria rede de dependências; co-produção de si mesmo e do contexto. Não há trabalho em ato (vivo) que não se apóie em algum trabalho prévio (morto). O desafio estaria em lidar com este fato inexorável e não prometer ou sugerir a possibilidade de fluxos espontâneos em que haveria criação ex-nihil. Nesse sentido admito que todo trabalhador, em alguma medida, estará obrigado a assumir algum grau de "funcionalidade". Todos somos, em algum grau, "trabalhadores funcionais" à organização, às necessidades e aos interesses dos outros, sejam usuários ou colegas de equipe. $E$ isto provoca mal-estar, sintomas; ou seja, exige formação de compromisso (Freud) ou o estabelecimento de contrato social com outros (Rousseau e vários autores de ciência política). A formação de compromisso e contrato evita a guerra de todos contra todos e assegura a possibilidade de convivência e de se trabalhar em prol de algum propósito. Ao mesmo tempo, todo trabalhador, em alguma medida, reagirá a esses constrangimentos externos; ou seja, à pressão da demanda, das necessidades de outros e das normas organizacionais. E reagirá a partir de seus próprios valores, desejos e interesses, o que o constituirá sempre como também sendo um "trabalhador moral"; isto é, alguém com objetivos, propósitos e diretrizes próprias, sejam elas assimiladas do meio ou não. Não concordo com Cecílio quando sugere que os valores morais do trabalhador adviriam somente, ou mesmo principalmente, dos chefes ou lideranças. O "trabalhador moral" é co-produzido a partir de fatores imanentes e transcendentes.

O método Paidéia opera ainda com o conceito de "ofertas", buscando produzir uma tensão dialética entre diretividade e não-diretividade da política, da gestão, da clínica e da saúde coletiva. Para este método os gestores, apoiadores e trabalhadores deveriam socorrer-se de referências originárias da tradição de um campo, do passado e de outras experiências para sugerir caminhos e arranjos que auxiliem a compreensão e ação sobre processos. E, note-se, as ofertas não são todas equivalentes. Sua potência e limite dependem da situação, mas também de seu conteúdo. A co-gestão, por exemplo. Como valer-se "do interrogar como metodologia" sem espaços coletivos democráticos para análise e deliberação? Como desconhecer no trabalho em saúde o efeito positivo - há farta bibliografia sobre o tema - de arranjos que facilitam e estimulam o vínculo e a horizontalidade da atenção? Como ser gestor ou apoiador sem problematizar posturas profissionais mecânicas, que mal avaliam riscos ou vulnerabilidade dos usuários e, em conseqüência, não acionam arranjos apropriados como são os programas de saúde ou os projetos terapêuticos singulares para proteger aos mais expostos? Tendo em vista a complexidade do processo saúde e doença, como conciliar com o hábito corporativo das especialidades e profissões de isolar-se e de fragmentar cada vez mais a atenção?

Gramsci falava na importância da reforma intelectual e moral; cognitiva e afetiva, política e ética diríamos hoje. O velho Aristóteles (384-322 a.C., 1987) escreveu: "Se não foste educado para seres bom, será obrigado pelo Estado a te tornares". Esta formação para a cidadania, para viver na Polis dependeria da educação das pessoas (Paidéia), da ética e da política. E ele continua: "Não é irrelevante, portanto, se formamos hábitos de um ou outro tipo..., faz uma grande diferença, na verdade toda a diferença". Cabe, portanto, aos legisladores, governantes (gestores da coisa pública) “... tornar bons os cidadãos incutindo-Ihes bons hábitos". A gestão é uma continuação da política com os 


\section{DEBATES}

mesmo e outros recursos, a reforma moral e intelectual continua nas organizações e durante o trabalho e o governante, o método de gestão, tudo isto participa das sínteses singulares realmente existentes.

Gostaria de ressaltar que o mérito do ensaio de Luis Cecílio é sua postura reflexiva e crítica. Luis Cecílio elaborou uma reconstrução do método dos filósofos helenistas céticos para pensar a gestão e o trabalho em saúde. Em grego, céticos (skeptikoi) significa literalmente "aqueles que se interrogam, aqueles que buscam," e jamais se conformam em aderir a dogmas ou verdades cristalizadas. A reflexão de Luis me obrigou a voltar-me sobre minha própria compreensão dos fatos, a explicá-los novamente, a abrir-me para novas possibilidades e novos entendimentos; por tudo isto valeu seu esforço, meu caro amigo.

\section{Referências}

ARISTÓTELES. Ética a Nicômaco. São Paulo: Nova Cultura, 1987. (Coleção os Pensadores, v.2).

CAMPOS, G.W.S. O anti-Taylor: um método para co-governar instituições de saúde com liberdade e compromisso. Cad. Saúde Pública, v.14, n.4, p.863-70, 1998.

Um método para análise e co-gestão de coletivos. São Paulo: Hucitec, 2000.

MARX, K.; ENGELS, F. A ideologia alemã (Feuerbach). 10.ed. São Paulo: Hucitec, 1996.

CASTORIADIS, C. Instituição imaginária da sociedade. Rio de Janeiro: Paz e Terra, 1982.

PICHON-RIVIÈRE, E. Teoria do vínculo. São Paulo: Martins Fontes, 1988.

O processo grupal. São Paulo: Martins Fontes, 1989. 